\title{
Biotin status, blood pyruvate carboxylase ( $E C$ 6.4.1.1) activity and performance in broilers under different conditions of bird husbandry and diet processing
}

\author{
BY C. C. WHITEHEAD AND D. W. BANNISTER \\ Agricultural Research Council's Poultry Research Centre, King's Buildings, \\ West Mains Road, Edinburgh EH9 3 JS \\ (Received 3 September 1979 - Accepted 3 December 1979)
}

\begin{abstract}
I. Three experiments were conducted to investigate the relationships between blood pyruvate carboxylase (pyruvate: carbon dioxide ligase (ADP-forming), EC 6.4.1.1; PC) activity, growth performance and dietary biotin level in broilers under different husbandry conditions. Blood PC activity was also used to gain information on the ingestion of biotin of faecal origin by birds housed on wood shavings and the effect of steam-pelleting on the biotin content of diets.

2. Blood PC activity and relationship to dietary biotin level were similar in birds kept under different husbandry conditions.

3. Biotin requirement for growth was higher in birds kept under conditions that allowed them to reach their growth potential more fully.

4. The contribution of biotin of faecal origin to the biotin intake of birds housed on wood shavings was negligible at 3 weeks of age but by 7 weeks was equivalent to approximately $0.01 \mathrm{mg} / \mathrm{kg}$ diet.

5. Steam-pelleting did not affect the stability or availability of biotin of natural or synthetic origin in diets.

6. It is concluded that blood PC activity is a good criterion of biotin status and requirement in fastgrowing broilers.
\end{abstract}

A sigmoid relationship between blood pyruvate carboxylase (pyruvate : carbon dioxide ligase (ADP-forming), EC 6.4.1.I; PC) and dietary biotin level was found in growing broilers and turkeys and it has been suggested that the activity of this enzyme represents a good criterion of biotin status in these birds (Whitehead \& Bannister, 1978a). The results of those studies, which used Marshall's broilers in small-scale experiments, suggested that the maximum enzyme activity occurred with dietary biotin levels considerably higher than those required for optimum growth.

The present experiments, using Ross broilers, were designed to investigate the relationship between enzyme and growth response to dietary biotin in larger-scale experiments under conditions that would allow the birds to reach more fully their genetic growth potential. When the relationship was found to differ from that observed in the earlier studies, a further small-scale experiment was conducted using Ross broilers to determine whether the difference was due to strain of bird or to method of husbandry. Other results from the large-scale experiments have been published already (Whitehead \& Bannister, 1978b).

The relationship of enzyme activity to biotin status was used also to investigate other aspects of bird husbandry and diet processing on biotin intake. Earlier studies on fatty liver and kidney syndrome (FLKS), a biotin-dependent condition, had shown that mortality was higher with pelleted diets (Blair et al. 1975). It was suggested that steam-pelleting might have destroyed or reduced the availability of some of the dietary biotin (Whitehead, 1977). A comparison was made therefore between the blood PC activities of birds given the same diets in either mash or pelleted form.

Biotin, like other B-vitamins, can be synthesized intestinally by micro-organisms. Although there is no evidence that biotin from this source can be absorbed directly by young chicks (Coates et al. 1968), it will, however, be excreted and floor-reared birds may ingest it through pecking their litter. In an attempt to quantify the contribution of this micro- 
Table I. Composition $(\mathrm{g} / \mathrm{kg})$ of basal diet

Ingredient

$\begin{array}{lc}\text { Wheat } & 750 \\ \text { Herring meal } & 120 \\ \text { Isolated soya-bean protein* } & 60 \\ \text { Vegetable oil } & 30 \\ \text { Limestone flour } & 16 \\ \text { Dicalcium phosphate } & 15 \\ \text { Methionine } & 3 \\ \text { Salt } & 2 \\ \text { Vitamin and mineral supplement } & 5 \\ \text { Ethoxyquin } & 0.5 \\ \quad & \\ \quad \text { Analytical composition } & \\ \text { Measured } & 227 \\ \text { Crude protein (nitrogen } \times 6 \cdot 25) & 54 \\ \text { Diethyl ether extract } & 0.098(\text { range } 0.093-0.105) \\ \text { Total biotin }(\mathrm{mg} / \mathrm{kg}) & 0.025 \\ \quad \text { Available biotin }(\mathrm{mg} / \mathrm{kg}) & 13.06 \\ \text { Calculated } & 0.100 \\ \quad \text { Metabolizable energy }(\mathrm{MJ} / \mathrm{kg}) & 0.033 \\ \text { Total biotin }(\mathrm{mg} / \mathrm{kg}) & \end{array}$

* Promine D; Oppenheimer Casing Co., Edinburgh.

† Supplied ( $/ \mathrm{kg}$ diet): retinol $2000 \mu \mathrm{g}$, cholecalciferol $20 \mu \mathrm{g}, \alpha$-tocopherol I7 mg, menaphthone I. $3 \mathrm{mg}$, riboflavin $4 \mathrm{mg}$, nicotinic acid $28 \mathrm{mg}$, pantothenic acid $10 \mathrm{mg}$, copper $3.5 \mathrm{mg}$, iodide $0.4 \mathrm{mg}$, iron $80 \mathrm{mg}$, magnesium $300 \mathrm{mg}$, manganese $100 \mathrm{mg}$, zinc $50 \mathrm{mg}$.

bially-produced biotin to the over-all intake of broilers, blood PC activity was measured in birds given the same diets but housed on either deep litter or wire floors.

\section{EXPERIMENTAL}

\section{Birds and husbandry}

The birds studied were Ross broilers, obtained as I-d-old chicks from a commercial hatchery (Ross Poultry Ltd, Inverurie AB5 9JE). In the large-scale experiments (Expts I and 2), the birds were housed in floor pens $\left(3 \cdot 72 \mathrm{~m}^{2}\right)$, forty-five birds per pen, containing a deep litter of white-wood shavings. In the small-scale experiment (Expt 3), the birds were accommodated in electrically-heated four-tier brooders, six birds per compartment as in previous experiments (Whitehead \& Bannister, $1978 a$ ). Food and water were freely available at all times and food consumption was measured weekly. Live weight was measured at $35 \mathrm{~d}$ and, in Expts $\mathrm{I}$ and 2, again at $56 \mathrm{~d}$.

Diets

The composition of the basal diet fed in the experiments is given in Table I. It was formulated to contain a low level of available biotin and hence was based mainly on wheat. Total and available biotin contents were calculated using the values of Frigg (1976, 1977). The theoretical total content agreed well with the values determined for the different batches by microbiological assay using the method of Wright \& Skeggs (1944). The available biotin content was found to be $0.025 \mathrm{mg} / \mathrm{kg}$, using an assay technique based on blood PC activity (C. C. Whitehead, unpublished observations), compared with $0.033 \mathrm{mg} / \mathrm{kg}$ calculated (Frigg, 1977).

The experimental diets were obtained by supplementing the basal diet with a commercial spray-dried preparation containing, in the batches used, $22 \mathrm{~g}$ D-biotin $/ \mathrm{kg}$ (Rovimix $\mathrm{H}_{2}$; Roche Products Ltd, Dunstable, Bedfordshire LU6 I BG). 
Pelleted diets were obtained by pressing the food through a die $(3 \mathrm{~mm}$ diameter) after treatment with steam at $140^{\circ}$.

\section{Enzyme assay}

Blood PC activity was measured by the method of Bannister \& Whitehead (I976) on samples of blood ( $\mathrm{ml}$ ) taken from the wing vein into heparinized syringes. In Expts I and 2, duplicate assays were performed on the pooled blood samples taken from ten birds chosen at random in each pen. In Expt 3, blood PC activity was measured in individual birds. For each effect studied, the assays were conducted over a $4 \mathrm{~d}$ period. Protein concentration was determined using an automated version of the method of Lowry et al. (1951) with haemoglobin as the standard. The enzyme activity was expressed as $\mathrm{nmol}{ }^{14} \mathrm{CO}_{2}$ incorporated/g haemoglobin per min at $38^{\circ}$; the units differ from those used previously (Bannister \& Whitehead, 1976; Whitehead \& Bannister, 1978a) since it has been established that, owing to an arithmetical error, the activities quoted in those papers were too low by a factor of ten.

\section{Procedure}

Expt $\mathrm{I}$. This experiment investigated the effect of dietary biotin level on growth and blood PC activity in both sexes. Mash diets supplemented with $0,0.02,0.05,0.09$ or $0.30 \mathrm{mg}$ biotin $/ \mathrm{kg}$ were each fed to four deep-litter pens of birds of each sex. Blood PC activities were measured in each pen during the fifth week.

Expt 2. This experiment studied the effect of dietary biotin level on growth and blood PC activity and the effects of wire $v$. litter floor and pelleting on biotin status in males. In the main experiment, seven diets (the basal mash diet supplemented with $0,0.04,0.08$, $0.10,0.13,0.20$ and $0.50 \mathrm{mg}$ biotin $/ \mathrm{kg}$ ) were each fed to four pens of birds on deep litter. Mash diets supplemented with $0,0.04,0.08$ and $0.10 \mathrm{mg}$ biotin $/ \mathrm{kg}$ were also each fed to birds in two pens in which a wire-mesh floor had been mounted $0.15 \mathrm{~m}$ above the litter. Batches of the diets supplemented with 0.04 and $0.08 \mathrm{mg}$ biotin $/ \mathrm{kg}$ were steam-pelleted and each was fed to four pens of birds on litter.

During the third and seventh weeks, blood PC activities were measured in the birds on wire floors and those on litter given the same diets. During the fourth week, activities were measured in the birds in the litter pens given the pelleted diets and the corresponding mash ones. In the fifth week, activities were measured in birds in all litter pens given mash diets.

Expt 3 . In the small-scale experiment, mash diets with the same supplemental biotin levels as in Expt 2 were each fed to male chicks in three brooder compartments. Blood PC activities were measured during the fifth week.

\section{RESULTS}

\section{Growth and blood PC activity}

Growth and food conversion values for the birds in Expts I and 2 up to 8 weeks of age have been published elsewhere (Whitehead \& Bannister, 1978b). Live weight and blood PC activity at 5 weeks are given in Table 2. Live weight was good and in both experiments there was a response to supplemental biotin. Blood PC specific activities also showed a marked response to dietary biotin level. In Expt I the mean activities of females were consistently higher than those of males fed the same level of biotin. Foot lesions characteristic of mild biotin deficiency were observed in both experiments only in the groups given the basal diet.

Corresponding values for Expt 3 are given in Table 3. There was a significant $(P<0.001)$ growth depression only among birds given the basal diet. However, blood PC specific activities showed a response over a wide range of biotin levels. Moderate to severe lesions of 
Table 2. Expts I and 2. Live weight and blood pyruvate carboxylase (pyruvate: carbon dioxide ligase (ADP-forming), EC 6.4.1.1;PC) activity of male and female broilers housed in floor pens and fed on diets containing different levels of supplemental biotin

(Blood PC activities, expressed as $\mathrm{nmol}{ }^{14} \mathrm{CO}_{2}$ incorporated/g haemoglobin per min at $38^{\circ}$, are means with their standard errors of duplicate assays on pooled samples from ten birds from each of four pens measured over a $4 \mathrm{~d}$ period. Live weights are means with their standard errors of means of each of four pens of forty-five birds)

\begin{tabular}{|c|c|c|c|c|c|c|c|c|c|}
\hline \multirow{3}{*}{$\begin{array}{c}\text { Expt } \\
\text { no. }\end{array}$} & \multirow{3}{*}{$\begin{array}{l}\text { Supplemental } \\
\text { biotin (mg/kg) }\end{array}$} & \multicolumn{4}{|c|}{ Live wt at $35 \mathrm{~d}(\mathrm{~g})$} & \multicolumn{4}{|c|}{ Blood $\mathrm{PC}$ activity during $5^{\text {th }}$ wee } \\
\hline & & \multicolumn{2}{|c|}{8} & \multicolumn{2}{|c|}{ 우 } & \multicolumn{2}{|c|}{$\delta$} & \multicolumn{2}{|c|}{9} \\
\hline & & Mean & $\mathrm{SE}$ & Mean & SE & Mean & SE & Mean & $\mathbf{S E}$ \\
\hline 1 & 0 & 872 & 15 & $8 \mathrm{I} 6$ & 17 & $24 \cdot 0$ & $3 \cdot 5$ & $28 \cdot 3$ & $5 \cdot 7$ \\
\hline & 0.02 & 980 & 3 & 871 & 9 & $40 \cdot 5$ & $2 \cdot 4$ & $48 \cdot 5$ & $7 \cdot 1$ \\
\hline & 0.05 & 1037 & 10 & $9 \mathrm{I} 7$ & 14 & $68 \cdot 7$ & $3 \cdot 3$ & $72 \cdot 2$ & 3. I \\
\hline & 0.09 & 1035 & 8 & 947 & II & $74 \cdot I$ & 5.0 & 83.0 & $5 \cdot 4$ \\
\hline & 0.30 & 1048 & 8 & 978 & 15 & 89.0 & $4 \cdot 3$ & 99.8 & $5 \cdot 2$ \\
\hline 2 & o & 911 & 10 & - & - & I6.7 & $1 \cdot 2$ & - & - \\
\hline & 0.04 & 1006 & 12 & - & - & $48 \cdot 5$ & $2 \cdot 3$ & - & - \\
\hline & 0.08 & 1080 & 7 & - & - & 72.9 & $2 \cdot 1$ & - & - \\
\hline & 0.10 & 1016 & 8 & - & - & 89.0 & $2 \cdot 3$ & - & - \\
\hline & 0.13 & $106 \mathrm{I}$ & 4 & $\longrightarrow$ & - & $92 \cdot 8$ & 3.4 & - & - \\
\hline & 0.20 & 1048 & II & - & - & $104 \cdot 2$ & 4.0 & - & - \\
\hline & 0.50 & 1059 & I 2 & - & - & $105 \cdot 2$ & $I \cdot 7$ & - & 一 \\
\hline
\end{tabular}

Table 3. Expt 3. Live veight and blood pyruvate carboxylase (pyruvate: carbon dioxide ligase (ADP-forming), EC 6.4.1.1;PC) activity of male broilers housed in wire cages and fed on diets containing different levels of supplemental biotin

(Mean values with their standard errors for eighteen birds/treatment. Activity, expressed as $\mathrm{nmol}{ }^{14} \mathrm{CO}_{2}$ incorporated/g haemoglobin per min at $38^{\circ}$, was measured over a $4 \mathrm{~d}$ period)

\begin{tabular}{|c|c|c|c|c|}
\hline \multirow{2}{*}{$\begin{array}{l}\text { Supplemental } \\
\text { biotin }(\mathrm{mg} / \mathrm{kg})\end{array}$} & \multicolumn{2}{|c|}{$\begin{array}{l}\text { Live wt } \\
\text { at } 35 \mathrm{~d}(\mathrm{~g})\end{array}$} & \multicolumn{2}{|c|}{$\begin{array}{l}\text { Blood PC activity } \\
\text { during 5th week }\end{array}$} \\
\hline & Mean & SE & Mean & $\mathrm{SE}$ \\
\hline 0 & 569 & 18 & 17.8 & $3 \cdot 2$ \\
\hline 0.04 & 987 & 32 & $46 \cdot 2$ & $4 \cdot 3$ \\
\hline 0.08 & 913 & 32 & $68 \cdot 2$ & $2 \cdot 4$ \\
\hline 0.10 & 997 & 33 & $78 \cdot 0$ & $4 \cdot 3$ \\
\hline 0.13 & 971 & 29 & $93 \cdot 3$ & $5 \cdot 5$ \\
\hline 0.20 & 1002 & 36 & $88 \cdot 4$ & $5 \cdot 1$ \\
\hline 0.50 & 943 & 24 & 87.0 & 4.6 \\
\hline
\end{tabular}

biotin deficiency occurred on the feet of many of the birds given the basal diet and mild lesions were seen on birds given $0.04 \mathrm{mg}$ supplemental biotin $/ \mathrm{kg}$. Lesions were not seen on the feet of birds given larger biotin supplements.

Response curves were plotted for both growth and enzyme values (Fig. 1). To enable results from Expts 1 and 2 to be analysed together, live weights and blood PC activities for each sex and in each experiment were expressed as percentages of the values occurring at the highest dietary biotin level in that group.

Quantitative assessment of the relationship between live weight at 8 weeks and biotin level had shown previously that exponential functions, such as of the Gompertz (1825) type, did not fit the values adequately and instead the response curve was drawn by eye (Whitehead \& Bannister, 1978b). A curve of the same shape (Fig. I) also gave a good representation of the live weight response of both sexes at 5 weeks and reached a plateau 


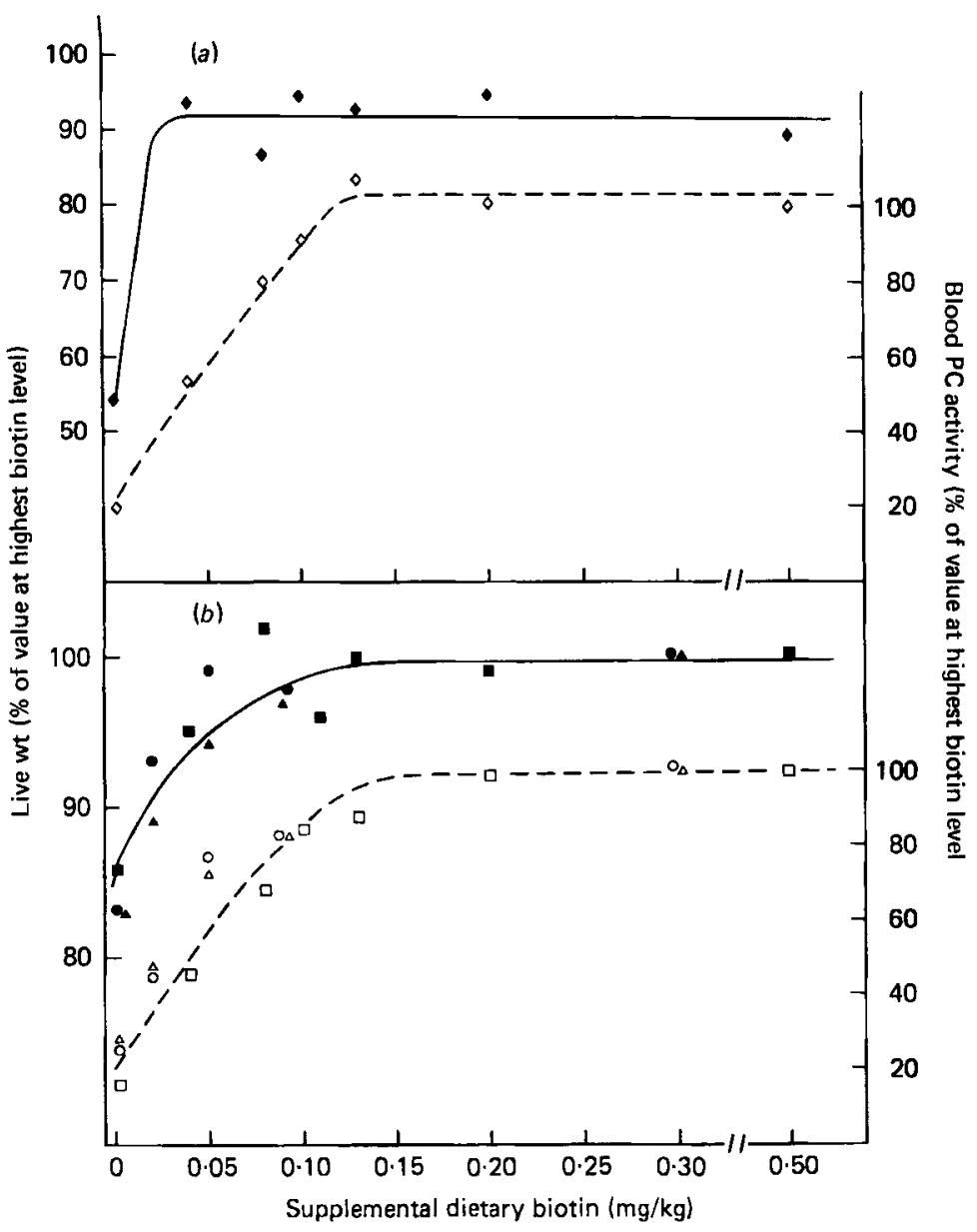

Fig. 1. Expts 1, 2 and 3. Responses of blood pyruvate carboxylase (pyruvate: carbon dioxide ligase (ADP-forming), EC 6.4.1.1; PC) activity (--) and live weight $(-)$ to different levels of supplemental dietary biotin in broilers at 5 weeks of age. $(O, \triangle, \square), \mathrm{PC} ;(O, \Delta, \boldsymbol{D})$, live weight for males $(O, \odot)$ and females $(\triangle, \Delta)$ in Expt 1 and males $(\square, \square)$ in Expt 2 ( $b$; large scale). PC $(\diamond)$ and live weight $(\diamond)$ are for males in Expt 3 ( $a$; small scale). At each biotin level, PC in Expts 1,2 and 3 and live weight in Expts $I$ and 2 are expressed as percentages of the value at the highest biotin level for that sex in that experiment; live weight in Expt 3 is expressed as the percentage of the mean live weight of males given the highest biotin levels in Expts 1 and 2 . The curves are fitted by eye.

at $99.8 \%$ of the maximum performance achieved. It was estimated from the curve that the supplemental biotin level required for optimum growth in Expts 1 and 2 was $0.14 \mathrm{mg} / \mathrm{kg}$.

Blood PC specific activity in Expts 1 and 2 showed a linear relationship with biotin over a range of dietary biotin levels. From the approach of the curve to the maximum, it was estimated that optimum enzyme activity occurred with a supplemental biotin level of 0.15 $\mathrm{mg} / \mathrm{kg}$.

The response curves for Expt 3 are also shown in Fig. I. Live weight at 5 weeks was expressed as a percentage of the mean live weight of males given the highest biotin levels in Expts $\mathrm{I}$ and 2 ( $1054 \mathrm{~g}$ ) in order to give an indication of relative performance in the largeand small-scale experiments. Mean live weight of all groups given supplemental biotin was 
Table 4. Expt 2. Blood pyruvate carboxylase (pyruvate ligase (ADP-forming), EC 6.4.1.1; $P C)$ activity in male broilers fed on mash or pelleted diets containing different levels of supplemental biotin

(Blood PC activities, expressed as nmol ${ }^{14} \mathrm{CO}_{2}$ incorporated/g haemoglobin per min at $38^{\circ}$, are means with their standard errors of duplicate assays on samples, pooled in batches of ten, from forty birds measured over a $4 \mathrm{~d}$ period)

$\begin{array}{ccccc}\begin{array}{c}\text { Supplemental } \\ \text { biotin }(\mathrm{mg} / \mathrm{kg})\end{array} & \overbrace{\text { Mean }}^{\text {Mash diet }} & \text { SE } & & \overbrace{\text { Mean }}^{\text {Pelleted diet }} \\ 0.04 & 59.5 & 3.0 & 58.0 & 3.4 \\ 0.08 & 74.9 & 5.3 & 72.8 & 4.3\end{array}$

$92.0 \%$ of the maximum achieved in Expts 1 and 2. Because of a lack of values at low biotin levels, the approach of the curve to the plateau could not be drawn with certainty, but, in view of the considerable growth depression of the unsupplemented group, it is likely that it occurred at approximately $0.03-0.04 \mathrm{mg}$ supplemental biotin $/ \mathrm{kg}$. In contrast, blood PC specific activity showed a linear response over a wide range of supplemental biotin levels and maximum activity was found to occur with a supplemental level of $0.13 \mathrm{mg} / \mathrm{kg}$.

\section{Pelleting effect}

The blood PC specific activities of birds given diets of similar biotin content in mash or pelleted form in Expt 2 are shown in Table 4. The differences between the two forms of either diet were not significant $(P>0 \cdot 1)$.

\section{Floor effect}

The effect of type of floor in Expt 2 on blood PC specific activities at 3 and 7 weeks of age is shown in Fig. 2. At 3 weeks there was no consistent effect of floor on enzyme activity but, by 7 weeks, the activities of all groups on litter floors were higher than those on wire floors given the same diets. These differences did not attain statistical significance at any biotin level $(P>0.05)$. However, when the values were combined and transformed to logarithms to stabilize the error variance, it was found that the 'floor' effect was significant $(t 3.32$, $7 \mathrm{df}, \boldsymbol{P}<0.02$ ). From the displacement of the enzyme response along the horizontal axis (Fig. 2) it was estimated that, at 7 weeks of age, birds on litter floors had a superior biotin status compared to those on wire floors equivalent to an extra dietary biotin intake of approximately $0.01 \mathrm{mg} / \mathrm{kg}$.

\section{DISCUSSION}

The results of these experiments indicate that blood PC specific activity is a good criterion of biotin status in growing broilers over a wide range of conditions of husbandry and performance and that it can be used to gain insight into several areas of nutritional interest.

One such area is the extent to which birds housed on litter can supplement their dietary intake by ingesting biotin of microbiological origin from the litter. Up to 3 weeks of age, when the proportion of faeces in the litter is comparatively low, the intake of biotin from this source must be small since there was no difference in blood PC specific activity between birds housed on litter or wire floors. However, the birds apparently obtained a small nutritional benefit from the much higher content of faeces present in the litter by 7 weeks since blood PC specific activity was then consistently higher in litter-housed birds. It was estimated that the enhancement in biotin status of these birds was equivalent to an extra 


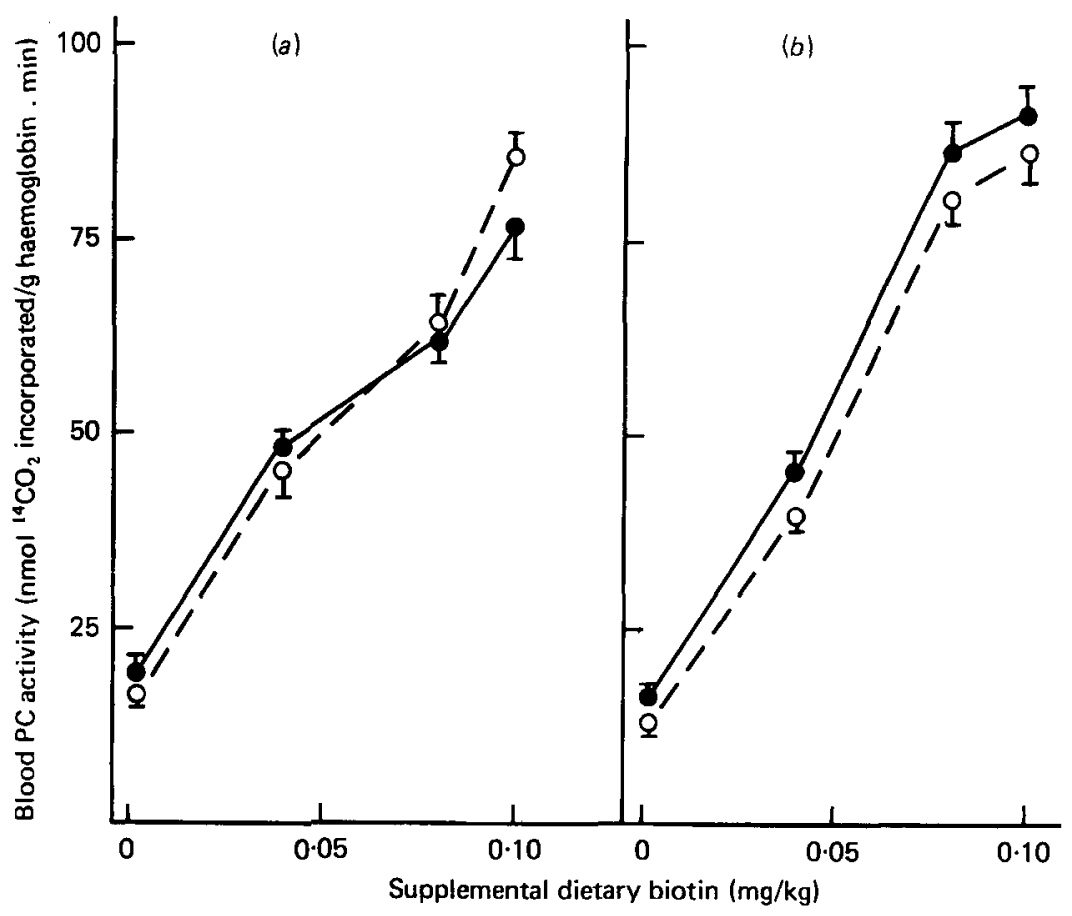

Fig. 2. Expt 2. Blood pyruvate carboxylase (pyruvate: carbon dioxide ligase (ADP-forming), EC 6.4. I I I PC) activity at $(a) 3$ and $(b) 7$ weeks of age in broilers housed in pens with floors of wire mesh $(\mathrm{O}-\mathrm{O})$ or wood shavings $\left(\mathrm{C}_{-}\right)$and fed on diets containing different levels of supplemental biotin. Mean values with their standard errors represented by vertical bars.

biotin intake of approximately $0.01 \mathrm{mg} / \mathrm{kg}$ diet. Confirmation of a benefit to the biotin status of birds on litter came from 8-week live-weight values (Whitehead \& Bannister, 1978 b) which showed a more severe growth depression on wire-housed birds given biotindeficient diets. On the basis of growth and enzyme values, it is estimated that the dietary biotin requirement of broilers for growth to 8 weeks of age is approximately $5-10 \%$ higher in birds housed in wire cages.

Blood PC activity was used to obtain information on the stability of biotin during diet processing. It has been thought that steam-pelleting might affect the biotin status of diets (Whitehead, I977) and mash diets were therefore used in the growth studies. However, blood PC specific activities were similar in birds given the same diets either in mash or pelleted form. There is thus no evidence that steam-pelleting, at least under the conditions used in the experiment, affects biotin content or availability in the diet. Moreover, since the diets contained supplemental biotin, the stability applies to biotin of both natural and synthetic origin. The explanation for the increased incidence of FLKS observed previously (Blair et al. 1975) with pelleted food perhaps lies in the greater food intake and growth rate of these birds.

Blood PC specific activity in Expt I was higher in females than in males at all dietary biotin levels, confirming previous indications with turkeys (Whitehead \& Bannister, 1978a) but activity in both sexes showed the same relationship with dietary biotin. Although enzyme specific activities were similar in males given similar levels of biotin in Expts I and 3, they were somewhat lower in Expt 2, perhaps as a result of some difference in analytical reagents or conditions. Nevertheless, the enzyme response to biotin was very similar in all experi- 


\section{C. C. Whitehead and D. W. Bannister}

ments. Enzyme specific activities at low dietary biotin levels as proportions of maximum activities in the same experiment were similar. Activity showed a linear relationship to biotin over a wide range of dietary biotin levels, as observed already by Whitehead \& Bannister (1978a) and the gradients were similar in both large- and small-scale experiments. It was estimated from the response curves (Fig. I) that maximum enzyme activity occurred with dietary biotin supplements of $0.15 \mathrm{mg} / \mathrm{kg}$ in Expts I and 2 and with $0.13 \mathrm{mg} / \mathrm{kg}$ in Expt 3, but this difference was not considered meaningful in view of the small number of plotted values influencing the curves in this region. From the previous discussion, it is unlikely that the different housing methods involved (litter $v$. wire floor) can have had more than a marginal effect on enzyme activities at 5 weeks of age.

From the response curve in Fig. I, the amount of supplemental biotin required for optimum growth was estimated to be $0.14 \mathrm{mg} / \mathrm{kg}$. On the basis of a basal diet content of $0.03 \mathrm{mg}$ available biotin $/ \mathrm{kg}$, the requirement of broilers kept on deep litter to 5 weeks of age is thus $0.17 \mathrm{mg}$ available biotin/ $\mathrm{kg}$. This level is adequate also for good skin condition, since even the lowest level of supplemental biotin $(0.02 \mathrm{mg} / \mathrm{kg}$ ) was sufficient to prevent dermal lesions. These conclusions are similar to those drawn from the 8-week values (Whitehead \& Bannister, 1978b) and suggest that the biotin requirement of the broiler may be higher than has been estimated previously (Anderson \& Warnick, 1970).

In the large-scale studies, when the birds were kept under conditions that allowed them to perform near to their genetic potential, there was a close relationship between the responses of blood PC specific activity and growth to biotin. In particular, both responses reached their maxima at similar dietary biotin levels. The activity of this enzyme may thus be a good criterion not only of biotin status but also of biotin requirement in the fast-growing broiler.

This relationship between enzyme activity and growth differed from that found previously in small-scale experiments with broilers of a different strain (Whitehead \& Bannister, $1978 a$ ). However, the small-scale experiment reported here, using the same strain as in the large-scale experiments confirmed that, when birds are prevented by environmental factors from achieving their maximum performance, there are differing effects on the responses of enzyme activity and growth to biotin. Reduced growth rate did not affect the relationship between enzyme activity and biotin. However, it did reduce the amount of biotin required to achieve the lower maximum growth rate. Growth in Expt 3 was significantly depressed only with the basal diet and, although the extent of the depression was large compared with that in Expts 1 and 2, it has been shown that keeping birds on wire floors will depress performance of birds given biotin-deficient diets (Whitehead \& Bannister, $1978 b)$. Growth with the lowest level of additional biotin $(0.04 \mathrm{mg} / \mathrm{kg}$ ) was good compared with that of groups receiving larger supplements. Although a response curve could not be fitted to the plotted growth values with certainty, it is probable that the requirement for optimum growth was approximately $0.03-0.04 \mathrm{mg}$ supplemental biotin $/ \mathrm{kg}$ and this conclusion is consistent with the results obtained in the earlier studies on birds housed in brooder cages (Whitehead \& Bannister, 1978 a). The housing conditions thus reduced the biotin requirement for growth; however, the more abrasive nature of the wire floor compared with litter increased the requirement for the prevention of foot lesions since these were still seen with a supplement of $0.04 \mathrm{mg}$ biotin $/ \mathrm{kg}$.

The plateau reached, with a supplement of $0.03-0.04 \mathrm{mg}$ biotin $/ \mathrm{kg}$, in the curve for growth response in Expt 3 corresponded to $92 \%$ of the live weight achieved in Expts I and 2. From the growth curve for Expts 1 and 2, the amount of supplemental biotin required to permit $92 \%$ of optimum performance was also approximately $0.03 \mathrm{mg} / \mathrm{kg}$. The similarity of these values suggests that, when the growth of birds is retarded, the requirement for biotin is reduced to approximately the level necessary to achieve that level of performance 
when the nutrient itself is the limiting factor. It is likely that the requirement established for any nutrient is highly dependent upon the absolute level of performance achieved. Thus estimates of requirements based on production characteristics are relevant only if the levels of performance of the experimental birds are comparable with those achieved in practice.

The authors thank Mr J. Armstrong and Mrs C. E. McNeill for technical assistance, Mr R. Morley Jones and Dr B. J. Wilson for assistance with statistical analyses and interpretation of results and F. Hoffman-La Roche \& Co., Basle, for biotin analyses of diets.

\section{REFERENCES}

Anderson, J. O. \& Warnick, R. E. (1970). Poult. Sci. 49, 569.

Bannister, D. W. \& Whitehead, C. C. (1976). Int. J. Biochem. 7, 619.

Blair, R., Whitehead, C. C. \& Teague, P. W. (1975). Res. vet. Sci. 18, 76.

Coates, M. E., Ford, J. E. \& Harrison, G. F. (1968). Br. J. Nutr. 22, 493.

Frigg, M. (1976). Poult. Sci. 55, 2310.

Frigg, M. (1977). Verh. Schweiz. naturf. Ges. 157, 340.

Gompertz, B. (1825). Phil. Trans. R. Soc. Ir5, 513.

Lowry, O. H., Rosebrough, N. J., Farr, A. L. \& Randall, R. J. (1951). J. biol. Chem. 193, 265.

Whitehead, C. C. (1977). Wld's Poult. Sci. J. 33, 140.

Whitehead, C. C. \& Bannister, D. W. (1978a). Br. J. Nutr. 39, 547.

Whitehead, C. C. \& Bannister, D. W. (1978b). Proc. XVI Wld's Poult. Congr., Rio de Janeiro, p. 1927.

Wright, L. D. \& Skeggs, H. R. (1944). Proc. Soc. exp. Biol. Med. 56, 95. 